\title{
"URUTAN" DAGING BABI FERMENTASI PRODUKSI PROGRAM PENGEMBANGAN KEWIRAUSAHAAN FAKULTAS PETERNAKAN UNIVERSITAS UDAYANA
}

\author{
Sumardani, N. L. G. ${ }^{1}$, B. R. T. Putri ${ }^{2}$, dan A. A. P. Putra Wibawa ${ }^{3}$
}

\begin{abstract}
ABSTRAK
Sosis fermentasi (urutan) daging babi merupakan salah satu produk pangan tradisional Bali yang dibuat dari cacahan daging dan lemak babi, dengan perbandingan daging dan lemak; 60 : 40, yang dicampur rempahrempah dan garam, dikemas dalam selongsong usus babi kemudian dijemur di bawah sinar matahari selama 3-5 hari lalu disimpan pada suhu ruang sehingga berlangsung fermentasi spontan. Urutan ini memiliki daya simpan selam 12 hari dalam keadaan baik dalam suhu ruang. Program Pengembangan Kewirausahaan (PPK) di Fakultas Peternakan Universitas Udayana memproduksi urutan daging babi fermentasi (udabafer) yang dibuat oleh mahasiswa. Adapun secara kualitas sudah di uji laboratorium, meliputi: kadar air, abu, protein, lemak, dan total mikroba. Dari hasil tersebut, udabafer produksi mahasiswa PPK masih layak untuk dikonsumsi dengan kadar lemak 34,0 \%; kadar protein 32,9\%; kadar abu 2,1\%; kadar air 42,23\%; dan total mikroba $8,1 \times 10^{7}(\mathrm{CFU} / \mathrm{g})$. Program pengembangan kewirausahaan sangat bermanfaat, khususnya bagi mahasiswa di Fakultas Peternakan agar terbangun motivasi untuk berwirausaha di bidang hasil-hasil peternakan.
\end{abstract}

Kata kunci : Sosis fermentasi, urutan daging babi, program kewirausahaan.

\begin{abstract}
Pork fermented sausages are one of the traditional Balinese food products made from chopped meat and fat, with a ratio of meat $(60 \%)$ and fat $(40 \%)$; mixed with spices and salt, packaged in pig intestine shells then dried in the sun for 3-5 days then stored at room temperature so that spontaneous fermentation takes place. This sequence has a 12-day shelf life in good condition room temperature. The Entrepreneurship Development Program at the Faculty of Animal Husbandry, Udayana University produces fermented pork sausages made by students. The quality has been tested in the laboratory, including: water content, ash content, protein, fat, and total microbes. From these results, the production of pork fermented susages is still suitable for consumption with fat content of $34.0 \%$; protein content $32.9 \%$; ash content $2.1 \%$; water content 42.23\%; and microbial total of $8.1 \times 107$ (CFU/g). Entrepreneurship development programs are very useful, especially for students at the Faculty of Animal Husbandry to build motivation for entrepreneurship in the field of livestock products.
\end{abstract}

Keywords: Fermented sausage, pork sausage, entrepreneurship development program.

\section{PENDAHULUAN}

\footnotetext{
${ }^{1}$ Fakultas Peternakan Universitas Udayana; nlg_sumardani@unud.ac.id

${ }^{2}$ Staf Pengajar Fakultas Peternakan Universitas Udayana; tanamaputri@unud.ac.id

${ }^{3}$ Staf Pengajar Fakultas Peternakan Universitas Udayana; aputrawibawa@unud.ac.id
} 


\subsection{Latar Belakang}

Sosis fermentasi (urutan) daging babi merupakan salah satu produk pangan tradisional Bali yang hingga kini masih diproses secara tradisional di Bali dan masih perlu mendapatkan perhatian untuk pengembangan lebih lanjut. Urutan daging babi ini dibuat dari daging dan lemak babi dengan perbandingan 60 : 40 (daging dan lemak), yang dicampur dengan rempah-rempah dan garam, dikemas dalam selongsong usus babi kemudian dijemur di bawah sinar matahari selama 3-5 hari lalu disimpan pada suhu ruang sehingga berlangsung fermentasi spontan. Urutan daging babi ini memiliki potensi untuk dikembangkan karena memiliki daya keawetan dan masa simpan produk selama 12 hari dalam keadaan baik pada suhu ruang. Hal ini berarti bahwa urutan daging babi memiliki keunggulan dalam menekan biaya penyimpanan karena tidak perlu alat pendingin yang memerlukan biaya relatif lebih mahal.

Urutan atau sosis menurut Aryanta (1996) digolongkan menjadi tiga yaitu: 1) sosis dari campuran daging, lemak, garam dan rempah-rempah, 2) sosis dari campuran daging, lemak, garam, rempahrempah dan gula, 3) sosis dari campuran daging, lemak, garam, rempah-rempah dengan penambahan gula dan nitrit. Sosis fermentasi seperti Salami, Pepperoni, Chorizo dan sebagainya, sudah dikenal dan dikonsumsi secara luas, sementara itu, urutan daging babi tidak populer di masyarakat Indonesia. Hal ini disebabkan pada aspek kehalalan, dan mutu urutan daging babi itu sendiri. Bahan baku yang menggunakan babi menyebabkan pemasaran dan konsumen produk ini masih terbatas pada kalangan non muslim. Sedangkan proses pembuatan urutan daging babi ini masih dilakukan secara tradisional, sehingga mutu produk yang dihasilkan tidak seragam.

Proses fermentasi spontan pada urutan daging babi hanya mengandalkan mikroba dari alam dan sangat berpengaruh terhadap mutu produk akhir. Resiko kegagalan sosis fermentasi (Hechelmann, 1986) adalah sangat tinggi karena mudahnya terkontaminasi mikroba perusak makanan. Keberhasilan untuk menghindari kerusakan dan kebusukan daging selama proses sangat tergantung dari ketepatan pengaturan parameter fermentasi selama proses untuk mengontrol faktor-faktor yang dapat meningkatkan keawetan daging, seperti $\mathrm{pH}$, mikroba, dan lain sebagainya.

Khusus untuk di Indonesia, sosis fermentasi sangat potensial dikembangkan karena kondisi iklim Indonesia rata-rata adalah bersuhu $18-38{ }^{\circ} \mathrm{C}$ dengan kelembaban udara berkisar antara $80-90 \%$. Kelebihan lainnya adalah tidak membutuhkan bahan baku daging yang ber $\mathrm{pH}$ tinggi sehingga tidak sulit untuk mengatur kondisi daging sebagai bahan baku. Dengan $\mathrm{pH}$ rendah akibat produksi asam selama proses fermentasi, sosis (urutan) ini dapat disimpan pada suhu ruang dan tahan lama. Sifatnya yang semi kering juga dapat memudahkan dalam penyimpanan serta pendistribusian.

Program Pengembangan Kewirausahaan (PPK) di Fakultas Peternakan Universitas Udayana memproduksi urutan daging babi fermentasi (udabafer) yang dibuat oleh mahasiswa secara berkelompok. Wirausaha menurut Agustina dan Sularto (2011) adalah orang yang menciptakan sebuah bisnis yang berhadapan dengan risiko dan ketidakpastian, yang bertujuan untuk memperoleh profit, dan mengalami pertumbuhan dengan cara mengidentifikasikan kesempatan dan memanfaatkan sumberdaya yang diperlukan. Sikap, motivasi dan minat mahasiswa sangat dibutuhkan bagi mahasiswa yang berwirausaha agar mampu mengidentifikasi peluang usaha, serta mendayagunakan peluang usaha untuk menciptakan peluang kerja baru. Peran Fakultas Peternakan Universitas Udayana dalam memotivasi mahasiswa, sikap dan menumbuhkan minat sangat penting dalam menumbuhkan jumlah wirausaha.

Oleh karena itu, dalam rangka mendukung Program Pengembangan Kewirausahaan di Fakultas Peternakan Universitas Udayana, maka dilakukan uji mutu terhadap produk yang dihasilkan yaitu urutan daging babi terfermentasi, sehingga nantinya produk ini dapat dipasarkan secara meluas.

\section{2 | BULETIN UDAYANA MENGABDI}




\section{METODE PELAKSANAAN}

Metode yang digunakan dalam pemecahan masalah ini melalui metode uji kualitatif (analisis produk) terhadap kualitas urutan daging babi yang diproduksi oleh mahasiswa yang tergabung dalam program pengembangan kewirausahaan di Fakultas Peternakan Universitas Udayana. Uji kualitatif meliputi kadar air, abu, protein, lemak, dan total mikroba. Sebagai pembanding dari produk urutan daging babi ini adalah urutan daging babi tanpa fermentasi. Uji kualitatif ini dilakukan di Laboratorium Fakultas Teknologi Pertanian Universitas Udayana. Sampel yang di analisis adalah 1) urutan daging babi tanpa fermentasi, 2) urutan daging babi dengan fermentasi, yang masing-masing diberi perlakuan penyimpanan yang sama.

Analisis data menggunakan t-test membandingkan dua produk urutan daging babi terfermentasi dan non fermentasi (Steel dan Torrie, 1980). Disamping itu juga, menggunakan metode analisis deskriptif kuantitatif, yang berusaha memberikan secara sistematis dan cermat fakta-fakta aktual dan sifat sampel tertentu. Dalam hal ini hanya menjelaskan, memaparkan, dan menggambarkan secara objektif data yang diperoleh dan data yang sudah terkumpul untuk memperoleh jawaban dari masalah.

\section{HASIL DAN PEMBAHASAN}

Hasil uji laboratorium terhadap produk urutan daging babi produksi mahasiswa program pengembangan kewirausahaan di Fakultas Peternakan Universitas Udayana (Gambar 1-3), adalah urutan daging babi terfermentasi yang diproduksi tersebut, masih layak untuk dikonsumsi. Urutan daging babi terfermentasi ini, berdasarkan hasil uji laboratorium menunjukkan kandungan kadar lemak 34,0 \%; kadar protein 32,9\%; kadar abu 2,1\%; kadar air 42,23\%; dan total mikroba 8,1 x $10^{7}$ $(\mathrm{CFU} / \mathrm{g})$.

Sosis fermentasi sangat potensial dikembangkan di Indonesia karena kondisi iklim Indonesia yang relatif sama dengan parameter pembuatan sosis. Sosis fermentasi umunya diperam pada suhu antara $18-45^{\circ} \mathrm{C}$ dengan kelembaban ruang fermentasi anatara 70-90\%. Keadaan ilkim di Indonesia adalah bersuhu $18-38{ }^{\circ} \mathrm{C}$ dengan kelembaban udara berkisar antara $80-95 \%$. Fermentasi merupakan cara untuk memproduksi berbagai produk menggunakan biakan mikroba melalui aktivitas metabolisme baik aerobik maupun anaerobik, yang bertujuan untuk mengawetkan, meningkatkan nilai gizi, dan memperbaiki cita rasa produk.

Mikroba yang bertanggung jawab selama fermentasi adalah Pediococcus cerevisiae dan Lactobacillus plantarum. Mikroba termasuk jenis bakteri asam laktat (BAL) homofermentif, karena selama fermentasi tidak terbentuk gas. Mikroba pembentuk asam laktat dalam sosis biasanya toleran terhadap konsentrasi garam antara 10-18\%. Mikroorganisme memegang peranan penting dalam sanitasi pangan karena mikroorganisme tertentu dapat menimbulkan penyakit dengan jalan mengkontaminasi makanan. Flavor yang menyengat disebabkan oleh akumulasi asam laktat dan komponen lain hasil metabolisme mikroba selama proses fermentasi, dengan $\mathrm{pH} 4,8-$ 5,4 . Sosis fermentasi ada dua jenis yaitu sosis kering (dry sausages) dengan kadar air 50\% dan sosis semi kering (semi dry sausages) dengan kadar air 35\%. Hal inilah yang menyebabkan flavor sosis kering lebih tajam dan memilki tekstur lebih keras.

Rempah-rempah atau bumbu adalah senyawa nabati yang dapat dikonsumsi dan berperan dalam pembentukan flavor yang diperkuat oleh pengasapan juga membentuk warna yang dapat menghambat oksidasi lemak. Bahan penyedap alami dapat ditambahkan pada produk daging dalam bentuk yang belum digiling, misalnya merica pada sosis kering. Namun biasanya ditambahkan 
bumbu yang sudah diproses, misalnya bubuk atau ekstrak. Bumbu merupakan bahan yang sangat penting dalam pembuatan sosis. Bawang putih mengandung $0,2 \%(\mathrm{w} / \mathrm{w})$ minyak atsiri yang memilki aktifitas antimikroba terhadap E. Coli, Staphylococcus, Serratia mercescens, dan Shigella dysentriae. Penambahan lemak dalam pembuatan sosis bertujuan untuk memperoleh produk sosis yang kompak, tekstur yang empuk, rasa dan aroma sosis yang lebih baik.

Jumlah mikroba yang cukup tinggi bisa disebabkan oleh kandungan berbagai jenis mikroba alami dalam daging seperti Enterobacteriaceae, Pseudomonas, dan lain-lain. Selain itu karena adanya kontaminsi diawal, saat penyembelihan, mikroba masuk melalui peredaran darah. Kontaminasi pula dapat terjadi melalui permukaan daging selama atau menjelang proses pendinginan, pembekuan dan thawing.

Adapun faktor-faktor yang mempengaruhi keawetan sosis fermentasi adalah bahan-bahan kimia yang ditambahkan yaitu bumbu dan gula, dominasi BAL (bakteri asam laktat) atas bakteri-bakteri lain dalam produk, nilai $\mathrm{pH}$ yang menurun tajan pada awal fermentasi namun kemudian meningkat diakhir fermentasi, dan pengasapan yang menghasilkan komponen pengawet pada permukaan sosis.

Secara umum, perkembangan total mikroba pada sosis fermentasi akan meningkat pada tahap awal fermentasi, kemudian agak stabil, dan akhirnya menurun pada akhir fermentasi. Fardiaz (1992) menyatakan bahwa jasad renik mengalami beberapa fase hidup yaitu fase adaptasi, fase pertumbuhan awal, fase logaritmik, fase pertumbuhan statis, fase menuju kematian, dan fase kematian. Fase adaptasi dan pertumbuhan awal terjadi saat conditioning selama 24 jam. Fase logaritmik terjadi setelah 2-3 hari fermentasi, fase statis pada 5-10 hari fermentasi, fase menuju kematian dan fase kematian setelah 15-30 hari fermentasi.

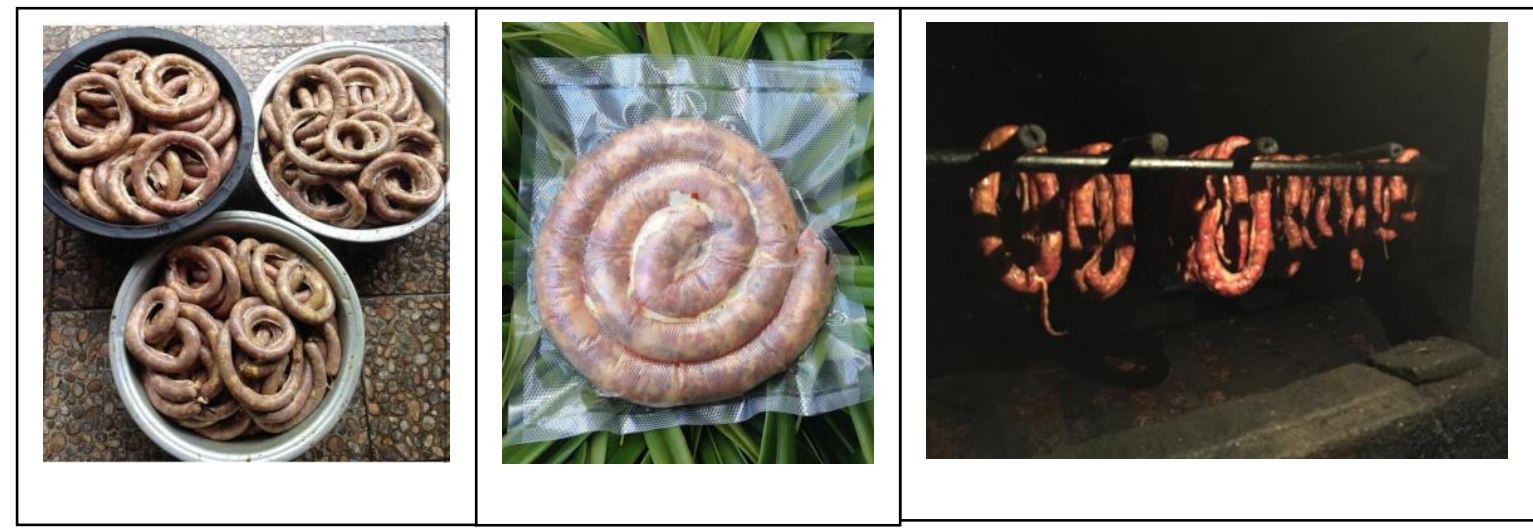

Gambar 1-3. Urutan daging babi terfermentasi

\section{KESIMPULAN DAN SARAN}

Dari hasil tersebut diatas dapat disimpulkan bahwa urutan daging babi fermentasi produksi mahasiswa yang tergabung dalam Program Pengembangan Kewirausahaan Fakultas Peternakan Universitas Udayana, masih layak untuk dikonsumsi, dan dipasarkan secara meluas.

Program ini sangat bermanfaat khususnya bagi mahasiswa Fakultas Peternakan agar terbangun motivasi untuk berwirausaha di bidang hasil-hasil peternakan

\section{4 | BULETIN UDAYANA MENGABDI}


Program Pengembangan Kewirausahaan (PPK) DIKTI sangat bermanfaat sehingga perlu dilaksanakan secara berkesinambungan dan melibatkan tenant yang baru ataupun tenant yang sudah mandiri,

\section{UCAPAN TERIMAKASIH}

Penulis mengucapkan terimakasih kepada DIKTI atas dana hibah Program Pengembangan Kewirausahaan 2019 di Fakultas Peternakan Universitas Udayana, dan kepada tim pelaksana, terimakassih atas bantuan dan kerjasamanya.

\section{DAFTAR PUSTAKA}

Aryanta, W. R. 1996. Karakteristik Sosis Terfermentasi Tradisional Bali. J. Ilmu dan Teknologi Pangan. Vol.1, No.2, Hal. 74-77

Fardiaz, S. 1992. Mikrobiiologi Pangan I. Penerbit Gramedia Pustaka Utama. Jakarta.

Hechelmann, H. 1986. Mikrobiell Verursachte Fehlfabrikate bei Rohwurst und Rohschinken. Fleischwirthschaff 66.

Steel, R.G.D. dan J.H. Torrie. 1980. Principle and Procedures of Statistics. McGraw-Hill Inc. New York. Diterjemahkan oleh: B. Sumantrini. 1993. Prinsip dan Prosedur Statistika. Jakarta: PT Gramedia Pustaka Utama.

Sardiana, IK., BRT Putri, IG Suranjaya, NLR Purnawan. 2015. Pengembangan Kewirausahaan di Universitas Udayana. Ngayah: Majalah Aplikasi IPTEKS 6 (1) 